\title{
GLOBAL CORPORATE SOCIAL RESPONSIBILITIES MANAGEMENT IN MNCS
}

\author{
Anupama Mohan \\ University of Warwick \\ Warwick, UK
}

\begin{abstract}
The management of global corporate social responsibilities (CSR) in MNCs is less understood. This paper presents an analysis of CSR management in the global operations of two MNCs of British origin operating in diverse sectors. The paper presents in-depth empirical analysis of CSR practices in routine stakeholder relations of these MNCs, across multiple levels within the MNC and across multiple levels of its context. The study reveals that global CSR management resulted from interplay of firms 'strategic choices, internal design processes, as well as influences of regulatory, normative and cognitive environment at the multiple levels of the MNC context.
\end{abstract}

\section{Introduction}

MNCs are under increasing pressure for socially responsible behavior in their global operations. However, global corporate social responsibility and the management of CSR behaviors in global operations remains less understood (Wood and Pasquero, 1997; Wartick and Wood, 1998; Freeman, 1997). The national business environments are increasingly promoting CSR (for example, see Bondy, Matten, Moon, 2004; Moon, 2004). Furthermore, there are several emerging global guidelines and voluntary initiatives seeking to improve CSR in global operations (Waddock, Bodwell, Graves, 2002). These trends in MNCs' environmental context need to be further supported by investigation of management of CSR in the global operations of MNCs and the environmental drive that influence global CSR management in MNCs. The present paper meets this gap by providing empirical study of management of global CSR in two MNCs of British origin. It provides a multilevel analysis of management of CSR in these firms, revealing several influences of the local, national and global environments on CSR management in these MNCs.

MNCs are complex differentiated networks marked with internal heterogeneity and with the complexity of managing across globally dispersed, diverse units (Bartlett and Ghoshal, 1989; Ghoshal and Nohria, 1989, Hedlund 1986, Hedlund \& Rolander, 1990). MNCs are faced with diverse stakeholder environments across their international operations. This has several implications for MNCs' management of stakeholder relations across the multiple levels and diverse contexts of its operations. Global CSR management also involves cross-border transfer and 
management of CSR practices, from one part of the MNC to another, as well as the management of local CSR practices suited to the local context of the subsidiary units.

The management of CSR in the global operations of MNCs, discussed in this paper, is an empirical in-depth investigation using an embedded sample of eight case studies across two MNCs of UK origin, and across four stakeholder dimensions within these MNCs. The analysis of self-reported CSR practices in these MNCs revealed the globally-managed CSR practices and their transnational management processes, as well as several CSR practices not transnationally managed across multiple units and levels of the MNC and also several local CSR practices.

The review of literature presents the existing understanding of management of global CSR and several arising unanswered questions. It notes that the management of CSR in global firms involves internal coordination processes, as well as environmental influences at multiple levels of MNC operations, however these are less understood. The exploratory study undertaken for this research, using multiple embedded case studies is then briefly presented. The empirical findings of MNCs' management of CSR in routine stakeholder relations, with employees, consumers, environment and communities are presented. Influences of the home country environment in the UK, as well as the global and local environments faced by these MNCs are analyzed. Then contributions of this research in advancing our understanding of CSR management in international operations are presented. Finally, the limitations of this research and avenues for future research are outlined.

\section{Conceptual Background}

Business is an inseparable and embedded part of the society. In addition to its economic role in society, business also has several other roles and responsibilities towards society (see Preston and Post, 1975; Davis and Blomstrom, 1971; Carroll, 1979; Margolis and Walsh, 2001), viz. responsible conduct of business activities while pursuing economic gains; the social and environmental responsibilities of the business towards its stakeholders; and business's contributions that would benefit the society at large (Margolis and Walsh, 2001; Sethi, 1975). Business responsibilities have been thus discussed in reference to the stakeholders of business (see Freeman, 1984; Clarkson, 1991; 1995) and the wider society.

The socialized view of business challenges the overtly 'economic-institution' or 'market-system' view of business held in the neo-classical economic traditions (e.g., Levitt, 1958; Friedman, 1970; Jensen, 1998). However, debates continue on CSR definitions, its scope (see Carroll, 1979; Schwartz and Carroll, 2003), and the motivations that guide CSR actions of business, i.e., business might be motivated by the instrumental role that CSR could play in achieving business interests (McWilliams and Siegel, 2001; Waddock and Smith, 2000a), or businesses might undertake CSR actions for their intrinsic good (Weaver et al., 1999). 
The term, CSR, in this paper, refers to a business organization's responsibility for integrating stakeholder concerns in routine business activities for primary stakeholders (employees, customers, suppliers), as well as environment (see Starik, 1995) and communities (see Burke, 1999) often are considered extensions of the primary stakeholders of the firm.

The international business domain offers a challenging context for inquiry into firm's CSR and ongoing stakeholder relationship management since there are many more and diverse stakeholders of international business firms (Wood and Pasquero, 1997). The MNCs are faced with wider CSR expectations, and MNCs are under increasing pressure for socially responsible behavior in their global operations.

The numerous and diverse stakeholders of MNCs include global customers, investors, creditors, global employees (Chamberlain, 1982; Amba-Rao, 1993; Gynawali, 1996; Amba-Rao, 1989); 'supra-national' level stakeholders, e.g., the UN and its agencies, the European Commission, the OECD; a variety of cross-border interest and activist groups, international NGOs championing issues such as consumer-protection, environment, safety, health-care, labour rights (Doh and Teegen, 2002; Sethi and Steidlmeier, 1990); local communities in home country as well as host countries; and the environment at the global as well as the local level. The communities in developing countries and the environment are often called 'weak,' or 'silent' stakeholders (Amba-Rao, 1993; Logsdon and Wood, 2002).

Moreover, CSR practices and stakeholder expectations vary across countries (Mohan, 2001; Maignan and Ferrell, 2001; Yoshimori, 1995; Broberg, 1996) and cultures, as values vary across cultures (Hampden-Turner and Trompenaars, 1993; Fukuyama, 1995; Hofstede, 1980; 1983). With varied underlying sociological and institutional paradigms, the societies may be monistic, dualistic or collectivist, individualist or communitarian (Lodge, 1978; Vogel, 1992; Sethi and Votaw, 1973) leading to divergent perspectives on the role and relationship of business with society, and hence the dominant definition of CSR in that society.

Furthermore, stakeholder expectations, critical social issues, norms, and values, and institutional and sociological requirements also change over time. CSR is behavior that is "congruent with prevailing social norms, values and expectations of performance" (Sethi, 1975 p. 62).

The temporal patterns of social issues (Lawrence et al., 2001) are also context specific. For example, while in the developed countries, some social issue might have been already addressed, and the related corrective and preventive business actions already institutionalized. At the same time, these issues might be still unknown, or only emerging in developing countries (see Reed, 2002; Khanna and Palepu, 1997; 2000; Amba-Rao, 1992; Mohan, 2001).

Thus, the social issues, social acceptance and societal expectations are differentiated across the world, both in space and in time. In operating across the spatially and temporally differentiated definitions and expectations of the 'role of business in society' across the globe, MNCs need to simultaneously manage across these diversities. 
Furthermore, MNCs' plural environments are collective and interconnected (Xu and Shenkar, 2002; Hart, 1992; Rosenzweig and Singh, 1991; Sundaram and Black, 1992; Westney, 1993). The complex legitimacy issues faced by MNCs (see Kostova and Zaheer, 1999; Hawkins and Walter, 1981) across these diverse political, economic, institutional and sociological environments are also discontinuous and marked with uncertainty and preclude universal corporate policies because what may be acceptable in one country or at a time may run counter to public policies or acceptable norms elsewhere or at other times (Logsdon and Wood, 2002; Sethi, 1975; Walter, 1975).

CSR in global operations is also influenced by several forces seeking to homogenize CSR across the world so that fundamental and universal social values are protected and upheld. These homogenizing forces include a variety of policy regimes at the global and national level. They include international guidelines (Kolk et al., 1999), bilateral or multilateral agreements among nation states, and trade treaties, e.g., NAFTA, WTO (Sanyal, 2001; Sethi, 2003). Several normative and descriptive standards of global CSR performance have emerged; such as the Human Rights Principles and Responsibilities for Transnational Corporations and Other Business Enterprises (UN Sub-commission on the Promotion and Protection of Human Rights 2002), the Tripartite Declaration of Principles Concerning Multinational Enterprises and Social Policy (ILO 1977), and, the OECD Guidelines for Multinational Enterprises (OECD 2000). Similarly, several voluntary initiatives and market based standards are emerging, such as the ISO, EMAS, SA, 8000 , AA1000 and the GRI, that seek to provide basic social and environmental standards for business operations across the world.

However, the discussions of international dimensions of CSR still remain in their infancy (Carroll, 1996; Amba-Rao, 1993; Wartick and Wood, 1998; Nehrt et al., 1970; Toyne and Nigh, 1997; Wood and Pasquero, 1997). Most existing models of CSR management in international business domain have focused on either social issues, crisis management (e.g., Brewer, 1992; Nigh and Cochran, 1987), or the attitudinal predispositions of firms' responsiveness, e.g., the RDAP proposed by Walter (1975) and Gladwin and Welles (1976). Little is known about MNCs" strategies for managing stakeholder relations with a multitude of stakeholders of varied salience, interfaced at multiple levels of the MNC.

International business operations involve responsiveness to differentiated local environments for some behaviors, and integration of behaviors across units for some other behaviors (Prahalad and Doz, 1981; Doz and Prahalad, 1991; Bartlett and Ghoshal, 1989). Typically, the HR and marketing practices are more locally responsive and therefore decentralized and differentiated, while the Finance or Accounting practices and procedures are more internally consistent and integrated across the MNC (Rosenzweig and Nohria, 1994). The differentiation/integration of $\mathrm{MNC}$ practices across the diverse environments involves the use of a combination of control and co-ordination mechanisms (Martinez and Jarillo, 1989) by the $\mathrm{MNC}$ for achieving integrated or differentiated practices in seeking legitimacy or efficiency gains. 
Many years ago Hawkins and Walter (1981) related management design and planning to CSR management in the MNC. In-depth analysis of organization design of CSR management and CSP of MNCs however still remains missing. More recently, Logsdon and Wood, (2002) typify MNC's CSR orientation as 'globally integrated' or 'multi-domestic' and suggest a 'hybrid strategy' of uniform globally applicable credos, and well defended local policies and codes to implement 'hypernorms' or universal values. Hansen (2002), based on a survey and case-studies of European MNCs' subsidiaries in Malaysia, China, and India, reported several elements of organization design of cross-border environment management, and proposed organizational typologies, drawing upon Bartlett \& Ghoshal (1989), i.e., 'decentralised' (no cross border management), 'international compliance,' 'centralised' (compliance to company-wide standards instead of local regulation), and 'globally integrated' (environment care initiatives stem from any unit).

Adopting the 'stakeholder orientation' perspective of CSR, Post et al. (2002) examined some global stakeholder relations in three MNCs of US origin and their operations in China, focusing on a variety of business activities across several stakeholder groups. A rigorous analysis of transnational management of CSR practices in routine (i.e., non-crisis) relations with stakeholders would further require a systematic inquiry into the MNC design and coordination mechanisms within the $\mathrm{MNC}$ and the environmental influences across the multiple levels of the MNC.

Moreover, the CSR practices have a normative basis, and those practices are both values-based and contextually determined. The CSR expectations, definitions and meanings are drawn from the context within which these occur. This peculiar nature of CSR practices makes their cross-border management difficult. Achieving consistent CSR practices across global operations involves not only the transfer of the CSR practice, but also the transfer of its underlying value and meaning. While, at the same time, faced with contextually diverse stakeholder expectations and local $\mathrm{CSR}$ requirements, $\mathrm{MNCs}$ also need to practice differentiated CSR at their local sites, in response to the local context. How MNCs meet these competing demands for managing CSR in their global operations and what determines their choices remains less discussed.

An empirical analysis of the management of stakeholder relations in MNCs was undertaken using a relational concept of CSR, i.e., on-going stakeholder relations in non-crisis situations, in routine business activities. This involved a within firm inquiry of CSR practices and their management in international operations, as well as a multi-level contextual analysis of influences in MNCs' environment. Findings from this study are presented and discussed here.

\section{Data and the Context}

An in-depth study (Yin, 1984; Denzin \& Lincoln, 2002) through multiple case studies (Eisenhardt, 1989; Yin, 1994) was conducted of eight embedded cases in two MNCs drawn from diverse business sectors. The embedded multiple case study design was adopted as a research strategy to study the phenomenon em- 
bedded in its nested multilevel context and to draw analytical and inferential generalizations (Yin, 1994; Gummeson, 2000). The cross-sector sampling (Pharmaceutical health-care, and Aviation-travel) ensured sufficient diversity of CSR sensitivities of the firms and diversity of stakeholder issues across the industry sectors (Post \& Berman, 2001). The home and host country context influences were minimized by drawing companies of the same country of origin (UK) and their operations in same host-country (India). This provided an illustrative case of global operations of MNCs and the opportunity to study multiple subsidiaries of the same MNC within a country. Two diverse contexts were also thus obtained for study, the developed country context (UK - Home country) and the developing country context (India - Host country). Multilevel access was obtained within these MNCs, at the head quarters (HQ), the subsidiary units in India, and the regional offices (ROs), and across the stakeholder dimensions. This resulted in a sample of eight embedded cases studies in the two MNCs: XA (Aviation-travel sector) and XB (Pharmaceutical health-care sector). The names of the companies have not been disclosed in order to preserve their anonymity.

Thus, CSR practices for stakeholder relations in non-crisis situations described by the managers at multiple levels within these eight cases were studied. The global management of these CSR practices was traced and pieced together from multiple data sources: key-informants' interviews across multiple levels, corroborated by documentary data sources across levels, departments, and functions along with investigation of relevant contextual influences at multiple levels of the context.

The contextual analysis (Pettigrew, 1985; 1995) provided an overview of the contextual setting that embeds the firms, and the institutional regulations, social norms and cognitive perceptions in the environment (Kostova, 1997; 1999; Scott, 1995) that influence CSR practices, at the global, national (UK and India), sectoral, industrial level (Health-care, Aviation-travel) and organizational levels. The analysis of these interconnected and embedded contexts revealed a longstanding emphasis on CSR in the national business environment in the UK and in India, as well as contemporary normative, regulatory and cognitive dimensions of the institutional context in these countries. Determinants of CSR conduct of international business organizations were also evidenced in several recent and emerging regulations and voluntary standards in the global business environment. Sector specific concerns and influences on CSR behavior were also noted.

Data analysis involved successive stages of coding, and patterns and themes matching within and across the two companies, across the eight cases and finally across CSR practices, following rigorous steps to ensure validity and reliability of research.

\section{Empirical Findings and Analysis}

The data reveal a variety of CSR practices within the MNCs, as well as systematic variation in global management of CSR practices. Several CSR practices were globally managed across the MNC levels; and several CSR practices dif- 
fered across the MNC units or were specific to the local operations. CSR practices within the MNCs varied across the stakeholder dimensions and within stakeholder groups. CSR practices also varied across MNC's subsidiaries in different countries and across MNC subsidiaries within the same country.

In the vision, mission and goals statements these MNCs stated their business objectives were to contribute to the wider societal benefit as well as to business returns. At the policy level these MNCs made a commitment to CSR in all their operations. For example, XA addressed the future viability of its business; the caring role of the company and XA stated its community relations and environment policy. In XB, corporate citizenship was part of the company's values statement.

CSR practices of these MNCs addressed socio-political, ecological, and environmental issues at the corporate level. Furthermore, these MNCs collaborated and partnered with governments and non-government organizations to address negative impacts of business activities and to solve several social problems. These firms also made corporate level commitment to transparency and social reporting and adopted at the HQ level, internationally recognized standards, such as AA1000, GRI, and ICC Charter for Sustainable Development.

XA's HQ reported the management of stakeholder relations across employees, customers, suppliers, shareholders, communities, and the environment in the global operations of XA, as well as XA's initiatives for promoting responsible tourism and various other social responsibility activities in the UK and in its international operations. XB's HQ reported environment, health and safety performance for the group, and its initiatives to protect biodiversity, animal rights and transparency of $R \& D$ and clinical trials.

Global policies for management of CSR across business operations were set at the corporate level in these MNCs. For example, in XA, Sustainable Business Unit (SBU), a corporate level department was set up to integrate social and environmental responsibility across functions in XA-UK and to transfer these practices to XA's sites world-wide. An Environment and Social Council was set-up in XA at the Board level that reviewed cross-functional issues and reported XA's CSR to the top management team.

These MNCs engaged in the review of CSR implications for their choices of the lines of business, use of resources and suppliers. For example, the social and environmental impact of aviation, travel and tourism, and pharmaceutical manufacturing businesses at the local operating sites, as well as at the global level were reviewed. Similarly, corporate level strategies that determine major lines of business of the MNC and the ways in which MNC links with its peers, investors, and suppliers, guided the decisions about choosing business lines and investments, e.g., minimize depletion of natural resources and pollution. The lines of business that had adverse effects were divested. Corporate-level decisions in these MNCs included the choice of technology, selection and guidelines for screening of suppliers, and waste management. These decisions were primarily taken by the HQ in XA. In XB, these decisions involved close consultation between the HQ and the subsidiaries. 


\section{Implementation of CSR Practices in Global Operations}

The implementation of CSR practices in global operations in these MNCs involved a variety of approaches, with varying involvement of the HQs and the subsidiaries. The CSR practices and their management in these MNCs are detailed below, across four stakeholder dimensions.

\section{Employee Dimension}

While the HR functions tend to be largely decentralized and more locally managed in MNCs (Rosenzweig and Nohria, 1994), the HQs of XA and XB had significant involvement in the management of some HR-related CSR practices in their global operations, often to varying extents of effectiveness. For example, XA's global policies for equal opportunities, bullying and harassment were available across the global operations through XA's intranet.

XA-UK reported its employee safety performance centrally, and employee training and employee satisfaction surveys were managed internationally in XA. The health and safety of employees in XB was globally managed in an integrated way through the XBWMS (integrated global manufacturing system of XB) and XBHELPS (XB's integrated system for management of health, safety, and environment, quality, and responsible procurement and supplies). The group policy on HSE, Equal Opportunity and Diversity, Quality, Policy on the Use of Animals in R\&D, the ISO standards, and the IFPMA guidelines were adopted across XB-HQ and all group operations.

On the other hand, CSR in most HR practices was largely locally managed. For example, in XA, equal opportunity practices, salary and benefits packages, or training and development of employees were largely locally managed by XA's local offices, often with a close involvement of the ROs. In XB, several HR-related CSR practices, e.g., salary and benefits, were locally managed and implemented in accordance with the local norms. While the group-wide equal opportunity policy of XB was laid by the $\mathrm{HQ}$, it did not require XB's local subsidiaries to report their performance by this policy.

\section{Customer Dimension}

Marketing, like human resource management, is often decentralized in the MNCs (Rosenzweig \& Nohria, 1994) in order for the local units to meet the differentiated needs of the local customers. The MNCs in this study illustrate variety of integration of CSR in global marketing practices. In both XA and $X B, C S R$ towards customers significantly involved the HQ through centralized or integrated management. Customer safety and security in XA were centrally co-ordinated through routines set by the HQ based on global regulations. In addition, the national regulations and norms were followed by the units. Customer feedback procedures comprised a mix of formal routines set by the HQ. Customer satisfaction and customer relations were globally managed through centralized IT networked processes, which were often outsourced services op- 
erating centrally designed templates. The brands and various 'point-of-contact' practices were standardised through global manuals and guidelines alongside which the local norms and approaches were also informally followed by XA's units.

In XB, the product portfolio of a unit was determined through the XBWMS, and the internal buyer supplier arrangements within the XB network. 'Product recall' was centralized, as were world wide drug donation practices. Product pricing was locally managed by XB units, often regulated by the national governments. However, when XB's units in Africa were faced with the issue of access and affordability of life saving drugs, XB-HQ centrally introduced several initiatives for improved access and subsidized pricing in developing countries through HQlevel partnership with UN and national agencies.

\section{Environment Dimension}

The existing discussions of environment care management in MNC operations (Hansen, 2003; Shrivastava, 1987a, b) place the responsibility for environment care somewhere between the HQ's and the local operations. In XA and XB the HQs were clearly accountable for the environmental performance of the global operations. The HQs took several measures to ensure implementation of environment care at the local sites either directly by the HQ, or by the local units. XA and XB HQs centrally reported their global environment care performance. In addition, XB's local units reported their environment care initiatives locally.

Environment care in XA was integrated by the HQ into functional areas, viz. global procurement, product design, and technical operations. These practices were primarily UK-centred with little involvement of XA's units even when these activities were done at an international local site. XA's annual environment report provided details of the regular monitoring and measure of the key characteristics of XA activities that may impact the environment in XA's global operations. These included reporting on global NOx, $\mathrm{CO} 2$ emissions, waste and noise control in its worldwide technical operations, global impact of tourism, compliance of international regulation in aviation, and several local issues in the UK, such as addressing congestion near airports in the UK. There were no significant environment care practices of XA's local sites. XA-UK was involved in a variety of wider environment care activities, e.g., initiatives to promote responsible tourism, preservation of ecosystems and partnership with the World Wild Fund for nature. These were directly managed by XA's UK-based departments without involving XA's local offices in the countries where these initiatives were conducted.

Care and protection of natural resources and biodiversity was adopted by XB's units as well as its suppliers, and third party contractors across XB's world wide operations as these practices were built into global manufacturing, R\&D and supply procurement procedures. Environment care in global operations of XB involved extensively integrated multilevel internal reporting and audit. These systems operated alongside XB's processes for participating voluntarily in numerous 
local environment care issues. XB-UK's membership in the WBCSD and ICC's Business Charter on Sustainable Development guided XB's environment-care initiatives and bio-diversity protection. These principles were encoded in the HSE, HELPS, and quality procedures for manufacturing and procurement. XB's units were, in addition, members of similar sustainable development and CSR organizations in the local countries.

\section{Community Dimension}

Community care by firms is typically localized at the sites of operation, i.e., the $\mathrm{HQ}$ and the subsidiaries in the case of MNCs. The MNCs studied here reveal several patterns of localization and centralization of community work. The UK operations of these MNCs had several impressive community care activities to their credit. In $\mathrm{XA}$ and $\mathrm{XB}$ some international community initiatives were centrally managed by the $\mathrm{HQ}$. XA and XB also illustrated some shared themes of community CSR practices across the global sites.

XA-UK adopted several community care initiatives throughout the UK. XA's local units similarly conducted charity and community support activities locally without the involvement of XA-HQ or other XA units. The 'charity' and 'care' themes were followed throughout XA's global operations. XA-UN programs were managed internationally, directly by the HQ even when these activities were conducted at XA's local sites, and these projects did not involve XA's local units. XA-HQ reported centrally, its worldwide community activities. XA's units were required to report their local projects to XA's central community contributions report towards XA's Percent Club membership in the UK, although XA-HQ was not involved in implementing or managing these activities at the subsidiary's sites.

XB-UK undertook several community care initiatives at its offices in the UK. $\mathrm{XB}-\mathrm{UK}$ was also involved in several global social development programs such as access to medicines in developing countries, health care and awareness. Several of the programs were directly undertaken by the HQ in its worldwide operations. Some CSR practices were shared across XB-HQ and its international units, e.g., the campaigns against counterfeit drugs, HIV-AIDS. Within XB, community activities, though apparently decentralized, were globally integrated through XB's corporate culture and awards, e.g., the Chairman's Corporate Citizenship awards. CSR practices were integrated into manufacturing, marketing, XBHELPS, and quality procedures. XB's units locally undertook activities such as innovative rural marketing for providing access to medicines for the poor people in remote villages.

\section{Discussion: The Management of CSR in Global Firms}

It is evident that these MNCs managed some CSR practices in their global operations. Several features of the 'CSR environment' in the UK influenced these firms to manage CSR in their global operations. Similarly, several factors in the global environment, emphasizing responsible business practices across interna- 
tional operations, also influenced global CSR management in these MNCs. Host country, as well as sector-specific, influences on global CSR were also evident. Firm level strategic choices of the MNC for global CSR management were also noted.

The global management of CSR practices involved implementing or transferring HQ's CSR practices to its local units. In addition the local units followed their own CSR practices. However, the HQs did not transfer or implement all CSR practices globally. Only select CSR practices were prioritized to be globally managed. A variety of reasons influence the selection of CSR practices for global management.

Evidently these MNCs adopted a variety of approaches for the global management of CSR practices. These approaches ranged from centralized, direct management, to integrated management, to decentralized management. MNCs' approaches varied across practices. Employee, customer, environment, or community-related CSR practices were not decentralized like HRM and marketing functions that are typically more decentralized. On the contrary, some select CSR practices within these functions were managed directly by the HQ or were centrally integrated. The reasons these MNCs accorded such importance to some CSR practices are discussed later.

Moreover, the CSR practices of the HQ often differed from those of the local units, when these practices were not linked across global operations. Thus, HQ's CSR practices were embedded in the local home country context, while the units followed the host country norms and CSR practices. CSR practices at the HQ level also differed from the CSR practices at the local units, even when these practices were transferred or implemented across the global operations. Practices were modified as they were adapted to the local environment. This local embeddedness of the local units is further discussed in a later section.

The preceding analysis of CSR practices in the global operations of two MNCs reveals interplay of several firm-level factors and national, global, and sectoral influences. A significant role of the HQ is evident in the global management of CSR, particularly in setting the guiding philosophy and corporate level policy for management of CSR in global operations of the MNC. Also, the HQ and the subsidiary units jointly participated in decisions regarding the social and environmental implications of business activities and the implementation of CSR practices. This was evident in XB and in some cases in XA. The UK-based operations of the MNC had several CSR practices that were often not transferred across operations and were limited to the UK. The local operations adopted several local CSR practices relevant to the local context. Furthermore, in these MNCs, committed to managing CSR in their global operations, the implementation of global CSR practices involved a variety of approaches, ranging from direct management by the HQ to varying extents of integration of CSR practices across the global units.

Evidently, only some CSR practices were selectively managed across the global operations in these MNCs. For example, while HR management was largely decentralized, the health and safety of employees was globally managed with 
the HQs being accountable for this performance. The selective prioritization of CSR practices for their global management within the MNC was influenced by the global and national factors, as well as MNC's own strategic priorities. The 'macro-global' homogenizing forces of the wider external interconnected environment lead to globally managed CSR practices. The CSR practices dominant in the home (UK) country were globally managed across the units by these MNCs.

The global context with its international guidelines, universal standards for performance and emerging legislation on several aspects of CSR practices also determined selective prioritization of CSR practices for their global management, e.g., the WHO directive on marketing practices which is followed by all units of XB worldwide and coordinated through IFPMA and its national and local chapters. The market-based certificates and voluntary standards for international business, viz. the ISO standards, and the GRI influenced the social and environmental performance reporting in these MNCs. XA-UK supported ICAO, the UN body responsible for setting environmental standards for civil aviation and noise standards for aircraft, as well as research and development on climate change and impact of aviation on the global atmosphere. XA-UK signed the ICC Charter for Sustainable Development and evaluated its performance for the year, against the ICC principles of sustainable development. Similarly, XA-UK supported research and innovation on issues such as European emphasis on noise around airports, night-time restrictions, EU's Hushkit regulation (1999) of marginally-compliant aircraft, global emissions and fuel efficiency, and waste management in the UK and Europe. The context thus influenced prioritization of select practices and provided the formal definition and standards for CSR.

Global homogenizing forces included the multinational clients and global business partners. In the XA example they were common contractors and partners across the XA network, the global interest groups and non-governmental organizations (Oxfam's role in the case of XB's drug-pricing issues), and MNC's membership networks such as the Percent Club.

At the national level, the home country national environment in the UK for these MNCs was marked by several factors promoting CSR including several UK legislations (Moon, 2004), viz. the Sex Discrimination Act (1975), the Equal Pay Act (1970), the Race Relations Act (1976), the Disability Discrimination Act (1995), the Code of Practice for Employment of Disabled People (1984), the Employment Relations Act (1999), the Human Rights Act (1998), and the Health and Safety Work Act (1974) that impose duties on the employers to ensure the health and safety $(\mathrm{H} \& \mathrm{~S})$ of their employees and to ensure that the H\&S of other persons is not adversely affected by the employer.

Moreover, the firms followed requirements of the UKLA's Combined Code (1992); UK Listing Authority guidelines, comprising Principles of Good Corporate Governance (1998) and Code of Best Practice; and the Turnbull Report (1999) that further expanded the Combined Code and provided guidance for the Directors to include the internal control requirements of the Combined Code. This required the Boards to identify and review the risks faced by their business opera- 
tions across the world as well as to introduce monitoring and control processes and annually report the compliance to these, to their shareholders. All London Stock Exchange listed companies are required to report in their annual report and accounts their adherence to these guidelines. For example, following the Combined Code, Principles of Good Governance and Code of Best Practice (1998) issued by the London Stock Exchange for its listed companies, XB reported its internal control in global operations, including financial, operational and compliance controls and risk management procedures, to its shareholders. Similarly, XA and XB also annually published an HSE performance report. HSE has been a growing concern since the Bhopal tragedy in 1984 where Union Carbide's plant leaked methyl isocyanate gas killing over 15,000 people in India. However, these reports portrayed the HSE management in the global operations to varying extent in these MNCs.

The UK national context is also marked by an active NGO and civil society influence on the normative and cognitive dimensions of CSR of British companies in their overseas operations. For example, Amnesty International Business Group, Oxfam, UK, the Prince of Wales International Business Leader's Forum, the Percent Club, and the Business in the Community Principles are some prominent NGO initiatives. The role of the Department for International Development (DfID) is part of the government initiatives to promote CSR of British MNCs.

Recent surveys of consumer and public opinion in the UK on CSR also report rising trends of consumer concern in the UK (MORI - CSR survey, UK, 2002, and the annual MORI polls since 1990). CSR is reported as an important consideration in the purchase decisions. Consumer activism, boycotts of products over concerns for environment and human rights have also been widely witnessed in the UK. Consumers and the public in the UK are noted to be sensitive to business practices in their overseas operations, e.g., recent campaigns against the use of child labour, bribery and corruption, and concern for environment-care, ethical sourcing, and workplace practices of overseas operations of British MNCs.

At the sectoral level, selective prioritization of some CSR practices for their transnational management was determined by the criticality of the issue within the sector or industry. Chemical and pharmaceutical industries focused on health and safety, and ethical marketing practices; while the travel-service sector focused on passenger security and safety. Implementation of these CSR practices was required by the sector specific institutions.

The host country environment also influenced selective prioritization of CSR practices. In many cases MNCs took selectively greater care to implement CSR in the host countries where institutional mechanisms to ensure responsible practices were lax, e.g., where the enforcement of environmental care was not up to world class standards. Similarly, in areas where child labour is rampant, the MNCs monitored their units as well as third party suppliers and contractors to ensure against incidences of child labor at worksites.

At the firm level, strategies of the $\mathrm{MNC}$ influenced the selective prioritization of some CSR practices for their global management, e.g., XA prioritized pas- 
senger, staff and aircraft safety and security, and its charity work; XB focused on quality and HSE, covering a variety of practices within these themes, which it integrated network-wide through specially designed management systems and cultural processes.

At the local level, influenced by the local context, several CSR practices of the local units of these MNCs were more isomorphic to the practices of the local firms, perhaps in an attempt to compete more effectively in the local markets (normative isomorphism) or to 'fit in' by imitating local practices (mimetic isomorphism) (DiMaggio and Powell, 1983), while instances of 'coercive isomorphism' for the legally stipulated behaviors were evident in local unit practices, such as the provision of provident fund, pensions, work-hours regulation, or training budgets for employees across global operations. For example, the subsidiary units in India followed several CSR practices consistent with the institutional, social or cultural norms of business behavior in India. Several non-statutory practices, such as employee-benefits given by local Indian businesses, were followed by the units of XA and XB. Examples include structuring salary packages, employee benefits such as the provision of private medical and health-care for employees and their families, housing and related amenities, conveyance and transport facilities, or support for children's education. These practices of the local units were nonisomorphic to the parent $\mathrm{HQ}$ or other units of the MNCs. These practices were planned, implemented and reviewed by the local managers in the country, sometimes with a close involvement of the RO. XB-India followed local pollution and emissions regulations, and XA-India followed the safety and security procedures required by the national civil aviation authorities.

Several HR- or customer-related CSR practices, well established in the UKbased operations of these MNCs, were not practiced in the international operations. Often there were no regulatory or other stakeholder pressures for conducting these practices globally, so their transnational management appeared to slack. For example, the normative and cognitive expectations predominant in the UK's national environment made it imperative for these MNCs to manage health and safety care towards their employees in global operations. However, these normative and cognitive expectations were missing in both the UK national, as well as the local country environment, for practices such as Equal Opportunity and Investor-in-people. Therefore these practices were not followed across the global operations in XA or XB.

Regulatory constraints preventing global CSR practices were also evident. Strict waste disposal and health and hygiene regulations in the UK constrained the donation of unused in-flight food to local charities in the UK while, at the initiative of cabin crew, this was easily done upon arrival of XA aircraft at the airports in India. Similarly, the national legal and financial institutions were noted to restrict employee share ownership in the international operations of these MNCs. In all countries, the law stipulated the conduct of employment relationships, but the varying scope of regulation across countries resulted in diverse behavior across the units within the MNC. For example, the working time, pay determination, rec- 
ognition of employee unions, consultative structures, and redundancy provisions, were defined by local legislation.

Furthermore, many practices, though designed to be managed transnationally, could not be implemented in the global operations, as these did not appear to 'fit' with the cultural or institutional contexts of the subsidiaries. XA's units did not find employee counseling, bullying and grievance procedures, or the Customer Listening Forums promoted by the HQ to 'fit' with the local business environment.

The above analysis of empirical findings across global and local CSR practices in these two MNCs reveals a fine-grained interplay of global, national-home country, host country level environmental factors, and firm's strategic choices and design for the management of CSR in global operations.

Hansen's (2003) typologies for configuration of cross-border management of responsibility in MNCs (i.e., Decentralised, International compliance, Centralised, and Globally integrated) are not evident as neat distinct types in this study. This fine-grained analysis on the other hand reveals these configurations to coexist as mosaic-like patterns within each MNC. The evidence suggests that within the typically decentralized functions, some CSR practices were much centralized, while some otherwise centrally controlled CSR practices, were not included in the international operations.

It is evident from this study that only select CSR practices were globally managed in these TNCs. The 'hybrid strategy' of uniform globally applicable credos, and well defined local policies and codes to implement 'hypernorms' suggested by Logsdon and Wood (2002) appears to be in place in these MNCs but only for select CSR practices. Thus, MNC's strategy for global management of CSR as 'globally integrated,' or 'multi-domestic' may not be firm level strategic orientation. The strategies vary across CSR practices. Thus, strategic CSR orientation may be described as a practice level orientation, varying from practice to practice, with some CSR practices of the MNC managed through a hybrid strategy, while, centralized or decentralized, global or multilocal approaches are followed for some other CSR practices.

This study suggests that the normative prescriptions for increased global CSR benefit from the recognition that global management of CSR requires strategic and systematic design for global management of CSR practices. Furthermore, the study suggests global CSR requires supportive environmental factors throughout the MNC's multilevel environment, i.e., the regulatory, normative and cognitive elements of the institutional environments at multiple levels of the MNC need to collectively support CSR practices for their global management.

\section{Conclusion}

This research looks within the MNC, and across its multilevel context, to report empirical and analytical findings of global management of CSR practices in two MNCs, across four stakeholder dimensions. 
This paper contributes to the understanding of global CSR, of which there was only scant existing discussion (Freeman, 1997; Wood and Pasquero, 1997; Logsdon and Wood, 2002). The current CSR management discussions are thus taken into the realm of international business, cross-border managerial issues, MNC design, and the heterogeneity and multiplicity of contexts in global operations.

These rigorous, empirically grounded and theoretically validated findings, have advanced the existing discussions of design and cross border management (Walter, 1975; Hawkins and Walter, 1981; Hansen, 2002; Post et al., 2002; Logsdon and Wood, 2002). These fine-grained findings reveal that global CSR management results from the interplay of firm's strategic choices, internal design processes, as well as the influences of regulatory, normative and cognitive environment across multiple levels of the MNC context - global, national, home country, local host country, and sectoral level.

The present study provides an account of global CSR management in MNCs of UK origin; future cross-country comparative studies would further extend this understanding. Similarly, future studies could include MNCs from other sectors in order to compare and contrast global CSR management approaches. The patterns, determinants and consequences of global CSR management identified in this exploratory study may be further extended through larger sample studies and large scale surveys.

\section{References}

Amba-Rao, S. C. (1989). Whither Bhopal: Technological hazards and social responsiveness in the third world. Social Development Issues, 12, 11-22.

Amba-Rao, S. C. (1992). Business social policy for the Third World: Response of the multinational corporate management. In K. E. Bauzon (Ed.), Development and democratization in the third world: Myths, hopes, and realities. New York: Taylor and Francis

Amba-Rao, S. C. (1993). Multinational corporate social responsibility, ethics, interactions and the Third world government: An agenda for the 1990s. Journal of Business Ethics 12, 553-572.

Bartlett, C. A. \& Ghoshal, S. (1989). Managing across borders: The transnational solution. Boston: Harvard Business School Press.

Bartlett, C.A. \& Ghoshal, S. (1995). Rebuilding behavioral context: Turn process reengineering into people revitalization. Sloan Management Review Fall, 11-23.

Bondy, K, Matten, D., \& Moon J. (2004). The adoption of voluntary codes of conduct in MNCs: A three-country comparative study. Business and Society Review, 109 (4), 449 $-477$. 
Broberg, M. P. (1996). Corporate social responsibility in the European communities - The Scandinavian viewpoint. Journal of Business Ethics 15, 615-637.

Burke, E. M. (1999). Corporate community relations: the principle of the neighbour of choice. Westport CT: Quorum Press.

Carroll, A. B. (1979). A three-dimensional conceptual model of corporate social performance. Academy of Management Review 4, 497-505.

Carroll (1996). Landmarks in the evolution of the Business and Society field. SIM Doctoral Consortium.

Chamberlain, N. W. (1982). Social strategy and corporate structure. New York: Macmillan Publishing Company.

Clarkson, M. E. (1991). Defining, evaluating, and managing corporate social performance: The stakeholder management model. In L. E. Preston (Ed.), Research in corporate social performance and policy (pp. 331 -358). Greenwich: CT: Jai Press

Clarkson, M. E. (1995). A stakeholder framework for analysing and evaluating corporate social performance. Academy of Management Review, 20, 92-117.

Davis, K. \& Blomstrom, R. (1971). Business, society and environment: Social power and social response. New York: McGraw-Hill.

Denzin, N. K. (1989). The research act: A theoretical introduction to sociological methods. Englewood Cliffs, NJ: Prentice-Hall.

Denzin, N. K. \& Lincoln, Y. S. (2002). Handbook of qualitative research. Thousand Oaks, CA: Sage.

DiMaggio, P. J. \& Powell, W. W. (1983). The iron cage revisited: Institutional isomorphism and collective rationality in organizational fields. American Sociological Review 48 . $147-160$.

Doh, J. P. \& Teegen, H. ( 2002). Nongovernmental organizations as institutional actors in international business: theory and implications. International Business Review, 11 . $647-663$.

Doz, Y. L. \& Prahalad, C. K. (1991). Managing DMNCs: a search for a new paradigm. Strategic Management Journal, 12, 145-164.

Eisenhardt, K. M. (1989). Building theories from case study research. Academy of Management Journal, 14, 532-550.

Eisenhardt, K. M. \& Bourgeois III, L. J. (1989) Building theories from case study research. Academy of Management Review, 14, 532-551. 
Epstein, E. M. (1976) The social role of business enterprise in Britain: An American perspective Part-1. The Journal of Management Studies, 13, 213.

Epstein, E. M. (1998). Business ethics and corporate social policy: Reflections on an intellectual journey, 1964-1996. Business and Society. 37, 7-40.

Etzioni, A. (1961). A comparative analysis of complex organizations. New York: Free Press.

Freeman, R. E. (1984). Strategic management: A stakeholder approach. Boston: Pitman.

Freeman, R. E. (1997) Managing the global economy: From relativism to multiculturalism. In B. Toyne \& D. Nigh (Eds.), International business: An emerging vision (pp. 131139). Columbia, SC: University of South Carolina Press.

Friedman, M. (1970, September 13) A Friedman doctrine - The social responsibility of business is to increase its profits. The New York Times Magazine, 32-33, 126.

Fukuyama, F. (1995). Trust: The social virtues and the creation of prosperity. New York: Free Press.

Gladwin, T. N. \& Welles, J. G. (1976), Environmental policy and multinational corporate strategy. In 1. Walter (Ed.), Studies in international environmental economics. New York: John Wiley \& Sons.

Glaser, B. \& Strauss, A. L. (1967). The discovery of grounded theory: Strategies for qualitative research. Chicago: Aldine.

Ghoshal, S. \& Nohria, N. (1989). Internal differentiation within multinational corporations. Strategic Management Journal, 10, 323-337.

Gummeson, E. (2000). Qualitative methods in management research. London: Sage.

Gupta, P. P. \& Dirsmith, M. W. (1994). Coordination and control in a government agency: Contingency and institutional theory perspectives on GAO audits. Administrative Science Quarterly, 39, 264-284.

Gynawali, D. R. (1996). Corporate social performance: An international perspective. $A d$ vances in International Comparative Management, 11, 251-273.

Hampden-Turner, C. \& Trompenaars, F. (1993). The seven cultures of capitalism. Value systems for creating wealth in the Unifed States. Britain, Japan, Germamy. France, Sweden, and the Netherlands. London: Piatkus.

Hansen, M. W. (2002). Managing the environment across borders: A study of TNC affiliates' environmental practices in China, Malaysia and India. Denmark: Samfundslitteratur. 
Hawkins, R. G. \& Walter, I. (1981). Planning multinational operations. In P. C. Nystrom \& W. H. Starbuck (Eds.), Handbook of organizational design (pp. 253-267). New York: Oxford University Press.

Hedlund, G. (1986). The hypermodern MNC: A heterarchy? Human Resource Management, 25, 9-36.

Hedlund, G. \& Rolander, D. (1990). Action in heterarchies: New approaches to managing the MNC. In C. A. Bartlett, Y. Doz, \& G. Hedlund (Eds.), Managing the global firm (pp. 15-46). London: Routledge.

Hofstede, G. (1980). Culture's consequences: International differences in work-related values. Beverly Hills, CA: Sage.

Hofstede, G. (1983). The cultural relativity of organizational practices and theories. Journal of International Business Studies, 14, 75-89.

Jensen, M. C. (1998). Purpose of change. In M. Beer \& N. Nohria (Eds.), Breaking the code of change (pp. 35-58). Boston: Harvard Business School Press.

Khanna, T. \& Palepu, K. (1997). Why focused strategies may be wrong for emerging markets. Harvard Business Review, 75, 41-51.

Khanna, T. \& Palepu, K. (2000). The future of business groups in emerging economies: Long-run evidence from Chile. Academy of Management Journal, 43, 268-285.

Kolk, A., Tudler, R., \& Welters, C. (1999). International codes of conduct and corporate social responsibility: Can transnational corporations regulate themselves? Transnational Corporations, 8, 143-180.

Kostova, T. (1997). Country institutional profile: concept and measurement. Best paper proceedings of the Academy of Management, 180-184.

Kostova, T. (1999). Transnational transfer of strategic organizational practices: A contextual perspective. Academy of Management Review. 24, 308-324.

Kostova, T. \& Roth, K. (2002). Adoption of an organizational practice by subsidiary of multinational corporations: institutional and relational effects. Academy of Management Journal, 45, 215-233.

Kostova, T. \& Zaheer, S. (1999). Organizational legitimacy under conditions of complexity: The case of the multinational enterprise. Academy of Management Review, 24 , 64-81.

Lane, C. (1992). European business systems: Britain and Germany compared. In R. D. Whitley (Ed.), European business systems: Firms and markets in their national context. London: Sage. 
Lawrence, T. R., Winn, M. I., \& Jennings, P. D. (2001). The temporal dynamics of institutionalization. Academy of Management Review, 26, 624-644.

Levitt, T. (1958). The dangers of social responsibility. Harvard Business Review, 34, 41 70 .

Lincoln, Y. S. \& Guba, E. G. (1985). Naturalistic inquiry. Beverly Hills, CA: Sage.

Lodge, G. C. (1978). The new American ideology. New York: Knopf.

Lodge, G. C. (1987). Introduction: ideology and country analysis. In G. C. Lodge \& E. F. Vogel (Eds.), Ideology and national competitiveness: an analysis of nine countries (pp. 1-28). Boston: Harvard Business School.

Logsdon, J. M. \& Wood, D. J. (2002). Business Citizenship: From Domestic to Global Level of Analysis. Business Ethics Quarterly, 12, 155-187.

Maignan, I. \& Ferrell, O. C. (2001). Antecedents and benefits of corporate citizenship: An investigation of French business. Journal of Business Research, 51, 37-51.

Margolis \& Walsh (2001). Misery loves companies: Shareholders, scholarship, and society. Academy of Management Annual Meeting, 2001.

Martinez, J. I. \& Jarillo, J. C. (1989). The evolution of research on coordination mechanisms of multinational corporations. Joumal of International Business Studies, 20 , 489-514.

Martinez, J. I. \& Jarillo, J. C. (1991). Coordination demands of international strategies. Journal of International Business Studies, 22, 429-444.

McWilliams, A. \& Siegel, D. (2001). Corporate social responsibility: A theory of the firm perspective. Academy of Management Review, 26, 117-127.

Miles, M. B. \& Huberman, A. M. (1984). Qualitative data analysis: A source book of new methods. Beverly Hills, CA: Sage.

Miles, M. B. \& Huberman, A. M. (1994). Qualitative data analysis: An expanded sourcebook. Beverly Hills, CA: Sage.

Mohan, A. (2001). Corporate citizenship: perspectives from India. The Corporate Citizenship Journal, 1, 107-117.

Moon, J. (2004). Government as a driver of corporate social responsibility: The UK in comparative perspective. Paper presented at the Academy of Management Meeting, New Orleans.

Nehrt, L. C., Truitt, J. F., \& Wright, R. W. (1970). International business research: Past, present and future. Bloomington, IN: Indiana University Press. 
Nigh, D. W. \& Cochran, P. L. (1987). Issues management and the multinational enterprise. Management International Review, 27, 4-12.

Nohria, N. \& Ghoshal, S. (1994). Differentiated fit and shared values: Alternatives for managing headquarters-subsidiary relations. Strategic Management Journal, 15, 491503.

Pettigrew, A. M. (1979). On studying organizational cultures. Administrative Science Quarterly, 24, 570-581.

Pettigrew, A. M. (1985). Contextualist research: A natural way to link theory and practice. In E. E. Lawler III, A. M. Mohrman Jr., S. A. Mohrman, G. E. Ledford Jr., \& T. G. Cummings (Eds.), Doing research that is useful for theory and practice (pp. 222-295). San Francisco: Jossey-Bass

Pettigrew, A. M. (1987). Context and action in the transformation of the firm. Journal of Management Studies, 24, 649-670.

Pettigrew, A. M. (1995). Longitudinal field research on change: theory and practice. In G. P. Huber \& A. Van den ven (Eds.), Longitudinal research methods: studying the processes of organizational change. London: Sage.

Post, J. E. \& Berman, S. L. (2001). Global corporate citizenship in a dot.com world: The role of organizational identity. In J. Andriof \& M. McIntosh (Eds.), Perspectives on corporate citizenship. Sheffield, UK: Greenleaf Pub., 66-82.

Post, J. E., Preston, L. E. \& Sachs, S. (2002). Redefining the corporation: Stakeholder management and organizational wealth. Palo Alto, CA: Stanford Business Books.

Prahalad, C. K. \& Doz, Y. L. (1981). An approach to strategic control in MNCs. Sloan Management Review, 22, 5-13.

Preston, L. E. \& Post, J. E. (1975). Private management and public policy. Englewood Cliffs, NJ: Prentice Hall.

Quazi, A. M. (1997). Corporate social responsibility in diverse environments: A comparative study of managerial attitudes in Australia and Bangladesh. Business and Professional Ethics Journal, 16, 67-84.

Reed, D. (2002). Employing normative stakeholder theory in developing countries: A critical theory perspective. Business \& Society, 41, 166-207.

Rosenzweig, P. M. \& Nohria, N. (1994). Influences on human resource management practices in multinational corporations. Journal of International Business Studies, 25, 229-251.

Rosenzweig, P. M. \& Singh, J. V. (1991). Organizational environments and the multinational enterprise. Academy of Management Review, 16, 340-361. 
Sanyal, R. N. (2001). The social clause in trade treaties: Implications for international firms. Journal of Business Ethics, 29, 379-389.

Schwartz, M. S. \& Carroll, A. B. (2003). Corporate social responsibility: A three-domain approach. Business Ethics Quarterly, 13, 503-530.

Scott, W. R. (1987a). The adolescence of institution theory. Administrative Science Quarterly, 32, 493-511.

Scott, W. R. (1987b). Organizations: Rational, natural, and open systems. Englewood Cliffs, NJ: Prentice-Hall.

Scott, W. R. (1995). Institutions and organizations. Thousand Oaks, CA: Sage.

Sethi, S. P. (1975). Dimensions of corporate social performance - An analytical framework. California Management Review, 17, 58-64.

Sethi, S. P. (2003). Setting global standards: Guidelines for creating codes of conduct in multinational corporations. Hoboken, NJ: John Wiley \& Sons, Inc.

Sethi, S. P. \& Steidlmeier, P. (1990). A new paradigm of business/society relationship in the Third world: The challenge of liberation theology. In W. C. Frederick \& L. E. Preston (Eds.), Business ethics: research issues and empirical studies (pp. 279-293). Greenwich, CT: Jai Press Inc.

Sethi, S. P. \& Votaw, D. (1973). A Berkeley view of business and society. California Management Review, 16, 95-100.

Shrivastava, P. (1987a). Bhopal. Anatomy of a crisis. Cambridge, MA: Ballinger.

Shrivastava, P. (1987b). Managing industrial crises: Lessons of Bhopal. New Delhi: Vision Books.

Silverman, D. (2000). Doing qualitative research: A practical handbook. London: Sage.

Smircich, L. (1983). Concepts of culture and organizational analysis. Administrative Science Quarterly, 28, 339-358.

Starik, M. (1995). Should trees have managerial standing? Toward stakeholder status for non-human nature. Journal of Business Ethics, 14, 207-217.

Sundaram, A. K. \& Black, J. S. (1992). The environment and internal organization of multinational enterprises. Academy of Management Review, 17. 729-757.

Toyne, B. \& Nigh, D. W. (1997). Business and society perspectives and international business. In B. Toyne \& D. Nigh (Eds.), International business: An emerging vision (pp. 111-115). Columbia, SC: University of South Carolina Press. 
Vogel, D. (1992). The globalization of business ethics: Why America remains distinctive. California Management Review. 35, 30-49.

Waddock, S., Bodwell, C. B., \& Graves, S. (2002). Responsibility: The new business imperative. Academy of Management Executive, 16. 132-148.

Waddock, S. \& Graves, S. B. (1997). Quality of management and quality of stakeholder relations: Are they synonymous? Business and Society, 36, 250-279.

Waddock, S. \& Smith, N. (2000a). Corporate responsibility audits: Doing well by doing good. Sloan Management Review, 41, 75-83.

Waddock, S. \& Smith, N. (2000b). Relationships: The real challenge of corporate global citizenship. Business and Society Review, 105, 47-62.

Walter, I. (1975). A guide to social responsibility of the multinational enterprise. In J. Backman (Ed.), Social responsibility and accountability (pp. 146-192). New York: New York University Press.

Wartick, S. L. \& Wood, D. J. (1998). International business and society. Malden, MA: Blackwell.

Weaver, G. R., Trevino, L. K., \& Cochran, P. L. (1999). Integrated and decoupled corporate social performance: Management commitments, external pressures, and corporate ethics practices. Academy of Management Journal, 42, 539-552.

Westney, E. D. (1993). Institutional theory and the multinational corporation. In S. Ghoshal \& D. E. Westney (Eds.), Organizational theory and the multinational corporation (pp. 53-76). New York: St. Martin's Press.

Wood, D. J. \& Pasquero, J. (1997). International business and society: A research agenda for social issues management. In B. Toyne \& D. Nigh (Eds.), International business: An emerging vision (pp. 139-159). Columbia, SC: University of South Carolina Press.

Xu, D. \& Shenkar, O. (2002) Institutional distance and the multinational enterprise. Academy of Management Review, 27, 608-618.

Yin, R. K. (1984) Case study research: Design and methods. Beverly Hills, CA: Sage.

Yin, R. K. (1994). Case study research: Design and methods. Thousand Oaks, CA: Sage.

Yoshimori, M. (1995). Whose company is it? The concept of the corporation in Japan and the West. Long Range Planning, 28, 33-45. 
Vol. 23, No. 1

Anupama Mohan obtained her Ph.D. degree at Warwick Business School, UK. Her research is across international business management, organization theory institutional theory, and strategy. She researches and teaches in business schools across Europe. Her work focuses on international dimensions of corporate responsibilities, transnational management of corporate responsibilities in global corporations, CSR in developing countries, and globalization and poverty. 